\title{
SANTRI DAN PENGUATAN PRAKTEK BELA NEGARA: STUDI KASUS PONPES SPMAA
}

\author{
Basyirun Adhim ${ }^{1}$
}

\begin{abstract}
Abstrak: Konsep Sistem Pertahanan Negara yang tersusun dalam UU RI No. 3 Tahun 2002 menyebutkan bahwa tugas pertahanan negara ialah menjaga dan melindungi kedaulatan negara, mempertahankan keutuhan wilayah NKRI dan melindungi keselamatan bangsa dari segala ancaman. Sebagai antisipasi ancaman ini, negara kita menganut konsep pertahanan integratif semesta yang memadukan semua potensi baik militer maupun unsur nirmiliter. Pondok pesantren dan komunitas santri sebagai komponen bangsa sekaligus ciri budaya dari kesatuan tak terpisahkan masyarakat Indonesia merupakan aset sumber daya pertahanan negara nirmiliter yang cukup potensial. Sejarah telah mencatat banyak peran taktis dan strategis mereka dalam perjuangan revolusi fisik merebut hingga mempertahankan kemerdekaan Negara Kesatuan Republik Indonesia. Dalam konteks kekinian, di saat negara kita menghadapi realitas ancaman aktual dan potensial yang kompleks, peran santri selayaknya dioptimalkan kembali secara integratif bersinergi dengan unsur pertahanan Indonesia lainnya. Intelektual bermoral, militansi tinggi, serta semangat jihad swadaya sukarela yang menjadi ciri figur santri dapat diarahkan kepada tindakan bela negara sekaligus unsur pembentuk komponen pertahanan cadangan.

Tulisan ini akan memaparkan praktek-praktek terbaik implementasi pembelajaran santri di pondok pesantren SPMAA Turi, Lamongan, Jawa Timur dalam kaitan peran taktis idealis strategis mendukung konsep pertahanan semesta dan kewajiban bela negara.
\end{abstract}

Kata Kunci:Santri, Pertahanan, Bela Negara, Nirmiliter.

\section{PENDAHULUAN}

Istilah pondok pesantren merupakan dua istilah yang menunjukkan satu pengertian. Pesantren menurut pengertian dasarnya adalah tempat belajar para santri, sedangkan pondok berarti rumah atau tempat tinggal sederhana terbuat dari bambu. Disamping itu, kata pondok mungkin berasal dari bahasa Arab Funduq yang berarti asrama atau hotel. Di Jawa termasuk Sunda dan Madura umumnya digunakan istilah pondok dan pesantren, sedang di Aceh dikenal dengan istilah dayah atau rangkang atau menuasa, sedangkan di Minangkabau di sebut surau.

Pondok pesantren di Indonesia memiliki peran yang sangat besar, baik bagi kemajuan pendidikan Islam itu sendiri maupun bagi bangsa Indonesia secara keseluruhan. Berdasarkan catatan yang ada, kegiatan pendidikan agama di nusantara telah dimulai sejak tahun 1596 . Kegiatan agama inilah yang kemudian dikenal dengan nama pondok pesantren (http://pendis.kemenag.go.id)

Secara umum pondok pesantren didefinisikan sebagai lembaga pendidikan

\footnotetext{
${ }^{1}$ Penulis: Basyirun Adhim. Pemerhati pertahanan. dapat
} dihubungi di gusadhimail@gmail.com yang memiliki 5 elemen pokok; (1) Pondok/Asrama: adalah tempat tinggal bagi para santri. Pondok inilah yang menjadi ciri khas dan tradisi pondok pesantren dan membedakannya dengan sistem pendidikan lain yang berkembang di Indonesia, (2) Masjid: merupakan tempat untuk mendidik para santri terutama dalam praktek seperti shalat, pengajian kitab klasik, pengaderan kyai, dll, (3) Pengajaran kitab-kitab klasik: merupakan tujuan utama pendidikan di pondok pesantren, (4) Santri: merupakan sebutan untuk siswa/murid yang belajar di pondok pesantren, dan (5) Kyai: merupakan pimpinan pondok pesantren. Kata kyai sendiri adalah gelar yang diberikan masyarakat kepada seorang ahli agama Islam yang menjadi pimpinan pesantren dan mengajarkan kitab-kitab klasik².

Dalam tradisi pembelajaran pondok pesantren, santri ditumbuhkembangkan melalui teladan keagamaan yang bersumber dari kajian tekstual, nilai-nilai ritual moral, serta praktek keteladanan amal sosial dari para pegiat di dalamnya (kyai, ustadz, kakak asuh). Ketiga unsur

\footnotetext{
${ }^{2}$ Tradisi Pesantren: Zamakhsyari Dhofier, 1982
} 
pembelajaran tumbuh kembang ini diharapkan mampu membentuk mental santri ideal yang berwawasan mondial universal, unggul secara etika moral, dan memiliki kecakapan hidup dalam tanggung jawabnya sebagai makhluk sosial. Dari sumber kajian tekstual para santri akan memiliki referensi jawaban yang memadai saat mereka dihadapkan pada dinamika kehidupan beserta problematika lingkungannya. Sedangkan dari pembelajaran nilai ritual moral, santri dituntut mampu hidup berpegang teguh pada dogma profetik yang mengedepankan asas iman meliputi ketuhanan, kemanusiaan, persatuan, keadilan, dan kebenaran.

Pada sumber pembelajaran ketiga, yakni keteladanan amal sosial para pegiat pondok pesantren, santri akan melihat langsung praktek cara hidup kepesantrenan di dunia yang seyogyanya. Peran keteladanan para pengelola pesantren akan diikuti para santri sebagai arah konkret pembelajaran yang selanjutnya diamal-sebarkan kepada masyarakat luas. Jumlah pondok pesantren kini mencapai 27.230 yang tersebar di seluruh Indonesia. Total jumlah santri semua pondok pesantren ini sebanyak 3.759.198 orang terdiri dari 1.886 .748 orang santri laki-laki $(50,19 \%)$, dan 1.872 .450 orang santri perempuan (49,81\%). Pendataan ini diolah oleh Pendis Kemenag pada tahun 2011-2012.

Kuantitas sumber daya manusia ini bisa dibaca sebagai alat pendukung komponen pertahanan yang cukup potensial, terutama dari unsur nirmiliter. Berkaca dari sejarah perjuangan melawan penjajahan hingga kemerdekaan era 1945, peran santri cukup signifikan memberi dukungan bagi tegaknya republik ini. Figur teladan signifikan dari pahlawan kemerdekaan yang dapat dilihat diantaranya adalah Pangeran Diponegoro yang mewakili tradisi kyai dan Panglima Besar Jenderal Soedirman yang menjadi representasi ikon pribadi santri.

Berkait konsep strategi pertahanan kekinian, khususnya bela negara, peran santri diarahkan menuju pelaksanaan doktrin pertahanan nirmiliter dimana tupoksi giatnya adalah perpaduan proporsional antara pengabdian pada profesi dan pengabdian pada kepentingan pertahanan negara ${ }^{3}$. Pondok pesantren dan santri ditanamkan pemahaman bahwa komponen pertahanan negara adalah domain publik. Artinya, amal pelaksanaan pertahanan nirmiliter dalam rangka membela negara adalah tanggung jawab bersama termasuk santri juga sebagai hak dan kewajiban warga Negara Kesatuan Republik Indonesia. Peran santri ini mencakup tindakan edukatif-antisipatif pertahanan nirmiliter terhadap spektrum ancaman serta medium palagan yang multi dimensi: ideologi, sosial, politik, ekonomi, hukum dan informasi.

Yayasan Pondok Pesantren Sumber Pendidikan Mental Agama Allah (SPMAA) didirikan oleh Bapak Guru Muhammad Abdullah Muchtar pada 6 Januari 1961 di Desa Turi Kecamatan Turi Kabupaten Lamongan Jawa Timur. Sebagai penggembala lembaga swadaya nirlaba yang memberikan layanan sosial pendidikan secara cuma-cuma, Bapak Guru MA. Muchtar memiliki visi "Agama dan Sifat Manusia Kembali Pada Aslinya" dalam mengimplementasikan pembelajaran di pesantren. Visi itu kemudian dirumuskan ke dalam kurikulum integratif yang memadukan metode salaf berdasarkan kearifan lokal (tradisional) dan sistem pesantren kholaf berbasis pengetahuan umum melalui sentuhan piranti teknologi informasi. Berbeda dengan ciri pondok pesantren pada umumnya yang lebih condong ke penguasaan literasi Islami, Yayasan Ponpes SPMAA lebih mendoktrin para santrinya untuk banyak berbuat manfaat yang langsung dapat dirasakan masyarakat, selain harus tetap memiliki kecakapan intelektual standar santri seperti tafsir kitab suci.

Sejak dini para santri di Yayasan Ponpes SPMAA dididik berpraktek dan dibiasakan dalam pembelajaran untuk berani mengorbankan kepentingan pribadi demi membela kepentingan agama, bangsa dan negara. Contoh pelaksanaan konsep ini pada terapan kurikulumnya, para santri harus memiliki kecakapan pribadi sebagai seorang pekerja sosial (social worker) yang secara ikhlas sukarela mendarmabaktikan waktu, tenaga, pikiran,

\footnotetext{
${ }^{3}$ Marsekal Madya TNI Eris Herryanto, S.IP., MA, 2012
} 
kepemilikan dan sumber daya hidupnya untuk melakukan misi pelayanan keumatan hingga istirahat wafat. Militansi pelayanan santri berbasis sosioreligi ini pada hakikatnya dapat diarahkan ke dalam rumusan doktrin pertahanan nirmilter yang berguna bagi bangsa dan negara. Figur santri yang berjatidiri intelektual bermoral dan pribadi berteladan uswatun hasanah Nabi dipurwarupakan menjadi kader santri bela negara berwawasan nusantara. Pada gilirannya jika konsep ini diadopsi dan direplikasi oleh lembaga pengelola pesantren lainnya, Indonesia akan memiliki unsur pendukung ketahanan nasional yang sangat memadai dan siap pakai.

\section{PEMBAHASAN}

Pembukaan Undang-Undang Dasar Negara Republik Indonesia Tahun 1945 menyebutkan, “..."Atas berkat rahmat Allah Yang Maha Kuasa dan dengan didorongkan oleh keinginan luhur, supaya berkehidupan kebangsaan yang bebas, maka rakyat Indonesia menyatakan dengan ini kemerdekaannya." Selanjutnya kalimat sakti ini dirumuskan dalam dasar negara PANCASILA yang menjadi sokoguru pembangunan bangsa dan pembentukan karakter manusia Indonesia. Santri Yayasan Ponpes SPMAA memahami pesan Pembukaan UUD 1945 dan Pancasila ini sebagai amanah kolektif khalifah penjaga bumi yang harus diawali dari keteladanan tanggung jawab pribadi. Kaidah fiqh syariah mengajarkan para santri tentang hak dasar manusia sebagai landasan pelaksanaan konsep bela negara, diantaranya adalah menjaga amanah kemerdekaan Indonesia beserta khazanah sumber dayanya yang di-fiqhkan sebagai harta titipan-Nya (hifzhul maal).

Dalam figh Islam ada lima hak dasar setiap manusia (adz-dzoruriah al-khamsah) yang sangat dijaga dan merupakan tanggungjawab peran setiap pribadi santri:

1. Hifzhud Diin (menjaga agama), bahwa perangkat syariat dan hukum Islam senantiasa diproyeksikan sebagai penjaga hak-hak dasar manusia dalam beragama. Prakteknya melindungi setiap penganut agama serta tempattempat ibadahnya. Maka setiap santri SPMAA memiliki kewajiban moral spiritual dan tanggungjawab sosial menjaga harmoni komunikasi umat beragama dalam semangat bela negara serta bingkai kerukunan Bhinneka Tunggal Indonesia.

2. Hifzhun Nafs (menjaga jiwa/nyawa), aturan Islam bertujuan menjaga nyawa atau keberlanjutan kehidupan manusia. Dalam konteks bela negara, peran santri memiliki tanggungjawab komunal menjaga keselamatan warga negara Indonesia dari berbagai spektrum ancaman. Konsep pertahanan nirmiliter dalam hal ini mengamanahi setiap santri menggagas cipta kondisi kamtibmas bersama giat unsur aparat, masyarakat dan komponen bangsa lainnya. Secare teknis santri memiliki kemampuan pemetaan teritorial supaya ancaman dari dalam seperti konflik horizontal, kerusuhan massal, bencana alam dan sosial, serta tindak kriminal dapat dicegah-tangkal sedini mungkin.

3. Hifzhul 'Aql (menjaga akal) aturan keagamaan disusun untuk menyelaraskan pengamalan nilai Islam dengan pendekatan akal dalam beberapa hal, sepanjang itu tidak bertentangan dengan prinsip ketauhidan dan teladan kerasulan. Pada prakteknya setiap santri dituntut mampu menjaga tradisi berpikir secara logika bela agama, bangsa dan negara dalam rangka menghadapi spektrum ancaman pendulum pemikiran (softpower) yang dapat menggoyahkan sendi-sendi kebangsaan pada kecenderungan radikal kiri ataupun radikal kanan.

4. Hifzhul Maal (menjaga harta) sistem aturan Islam mengakui hak-hak individu dalam menjaga harta sekaligus mengarahkan tanggung jawab sosial setiap kebermanfaatan properti pribadi individu itu dalam peramalan kemasyarakatan. Relevansi konsep menjaga harta (hifzhul maal) dan praktek pertahanan Negara mengharuskan setiap santri memiliki tanggung jawab menjaga sumber daya "harta" Indonesia meliputi aspek kekayaan trimatra dan potensi 
strategis astagatra bersama-sama garda bela negara dari unsur nirmiliter lainnya.

5. Hifzhun Nasl (menjaga keturunan dan kehormatan), perangkat aturan Islam memfardlukan para pengimannya supaya menjaga nasab keturunan dan menjaga martabat kehormatan anak manusia. Setiap santri yang berprinsip bela negara akan menjaga keberlanjutan generasi negeri ini beserta marwah kehormatannya dari ancaman pencemaran moral dan perusakan mental.

\subsection{Peran Pembelajaran Santri SPMAA dalam Praktek Giat Bela Negara}

Santri SPMAA memiliki motto Berdoa,

Belajar, Bekerja dan dikombinasikan sesanti Ingat Allah, Ingat Mati, Kasihi Sesama. Motto dan sesanti ini diformulasikan dalam kurikulum pembelajaran integral yang diatur ketat berjadwal dengan pola pengasuhan asrama. Bobot kajian teori lebih dipadatkan pada praktek pengamalan dengan pengawasan terbimbing. Sebagai kerangka acuan pelaksanaan kurikulum pembelajarannya, santri dikondisikan belajar melalui referensi panduan tiga program utama Yayasan Ponpes SPMAA yakni Pendidikan, Kesejahteraan Sosial dan Pelestarian Sumber Daya Alam dan Lingkungan/ Keanekaragaman Hayati. Secara teknis tiga program utama ini diuraikan dalam kelas praktikum keterampilan dan pos-pos kegiatan santri yang berkelompok. Khusus untuk bidang minat keahlian yang lebih spesifik, santri diberikan pilihan belajar mandiri dengan tetap di bawah pengawasan dan pengasuhan. Beberapa kecakapan harus dimiliki setiap santri sebagai syarat wajib mendapatkan telaah penilaian dan ijazah kelulusan, seperti materi pelayanan pekerja sosial (social worker) serta pengasuhan santri lanjut usia (caregiver cadre).

Berkait konsep pertahanan negara yang bersifat integratif, Yayasan SPMAA menganut kebijakan pembelajaraannya pada aspek pendekatan kesejahteraan. Ponpes SPMAA percaya bahwa stabilitas dan kekuatan pertahanan akan mampu diramu secara efektif jika kesejahteraan suatu masyarakat sudah mulai terlihat adil dan merata di semua strata. Untuk itu, para santri di Ponpes SPMAA dibiasakan supaya bergiat mendahulukan kesejahteraan masyarakat daripada kesejahteraan dirinya. Di lingkup terkecil dalam lingkungan asrama maupun nonasrama, prinsip ini diberlakukan melalui latihan harian, syarat kecakapan kepribadian dan unit kegiatan-kegiatan penugasan. Berikut kegiatan praktekpraktek terbaik unit kegiatan pembelajaran santri Yayasan Ponpes SPMAA yang mengabdi pada profesi santri dan bekerja atas prinsip kesadaran bela negara:

\subsubsection{SANTANA (Santri Tanggap Bencana) \\ SANTANA (Santri Tanggap Bencana)} ini lahir seiring berdirinya Yayasan Ponpes SPMAA yang diawali kiprah keteladanan amal sosial Bapak Guru MA. Muchtar. Beliau pada tahun 1966 melihat kondisi Kabupaten Lamongan wilayah cluster tengah yang kerap dilanda banjir dan secara geografis terisolir. Maka beliau pun berinisiatif mengajak keluarga dan santrinya untuk ambil peran penyelamatan evakuasi korban dan pendirian rumah penampungan. Dari sini awal giat SANTANA mulai diikhtiari dan ditetapkan menjadi unit kegiatan kelembagaan di bawah naungan program layanan Kesejahteraan Sosial. Hingga saat ini unit kegiatan SANTANA terus bergerak membantu ke setiap medan kebencanaan di berbagai penjuru tanah air mulai dari Aceh hingga Papua. Dalam setiap misinya SANTANA mengirim tim taktis sesuai analisa kebutuhan di lapangan dan sumber daya yang tersedia. Koordinasi bersama TNI/Polri serta instansi terkait menjadi juklak juknis wajib bagi pegiat SANTANA. Sesuai dinamika tuntutan keadaan, kini SANTANA telah mengembangkan layanan dan organ kelengkapan misi bantuan. Organ SANTANA dibagi menjadi 7 tim terlatih (1) MEDISANTANA yang melayani bidang kesehatan; (2) EVAKUASANTANA tim penyelamatan dan evakuasi korban; (3) INFORMASANTANA tim penyedia informasi data beserta piranti teknologi dukungnya; (4) LOGISANTANA tim penyedia logistik relawan dan perlengkapan misi layanan; 
jawab transportasi; (6) EDUKASANTANA tim khusus layanan pendidikan di kondisi kegawatdaruratan yang terangkai dalam sistem dukungan rehabilitasi pemulihan dan konsultan psikososial korban (survivor psychosocial support);

DISTRIBUSANTANA tim penjangkauan dan penyaluran bantuan. Layanan SANTANA difokuskan pada survivor anak, wanita dan lanjut usia (AWAL).

Setiap santri SPMAA diharuskan memiliki syarat kecakapan pribadi sebagai seorang sukarelawan SANTANA yang oncall siap dan tanggap digerakkan ke area bencana di wilayah Indonesia. Pada pembagian tugasnya nanti, santri akan menyesuaikan kapasitas keterampilannya dan sumber dayanya ke organ SANTANA yang ada. Prinsip etos kerelawanan kerja layanan SANTANA didasarkan pada niat dan semangat menjaga nyawa manusia (hifdzunnafs) sebagai aset berharga milik bangsa yang harus dibela serta diselamatkan.

\subsubsection{Komunitas Santri Informatika}

Unit kegiatan pondok pesantren ini khusus mewadahi serta menyalurkan potensi santri yang giat menekuni dunia komputasi dan piranti teknologi informasi. Bidang garapan layanan dan fokus pembelajaran diarahkan pada pembentukan santri penjaga dunia maya, mencakup di dalamnya pemanfaatan piranti keras dan piranti lunak untuk alat kebermanfaatan umat. Disadari bahwa kehadiran piranti teknologi informasi merupakan keniscayaan dinamika jaman yang pasti dan sulit dihindari. Maka para santri ditanamkan kesadaran, bahwa piranti teknologi informasi harus dimanfaatkan untuk sebesar-besarnya kebaikan masa depan kemanusiaan, khususnya demi marwah bangsa dan negara. Spektrum informasi dan medium teknologi harus digerakkan menjadi piranti penyampai pesan-pesan ketuhanan, norma kemanusiaan, jiwa persatuan, korsa kebangsaan, dan etika keadilan. Produk layanan unit kegiatan Komunitas Santri Informatika ini diantaranya kampanye penggunaan piranti lunak legal dengan berbasis sumber kode lisensi terbuka Freeware/ Open Source Software (F/OSS). Melalui kampanye Pesantren Open Source
- Madrasah Open Source (POS-MOS), santri Ponpes SPMAA berdakwah materi kehalalan sistem komputasi ini ke pondok pesantren, madrasah, masyarakat dan instansi pemerintah.

Melalui kajian fiqh komputasi yang dikemas dalam acara rutin "Ngaji Bahtsul Masail Linux", unit kegiatan Komunitas Santri Informatika ini membangun dan menanamkan kesadaran tentang bahaya laten ancaman tindak kejahatan pencurian lewat penggunaan piranti lunak bajakan. Kejahatan laten ini kerap tidak disadari oleh masyarakat luas, terutama di lingkungan beragama. Santri Informatika dengan kampanye POS-MOSnya menawarkan hijrah sistem operasi plus dunia komputasi alternatif yang lebih murah, relatif mudah dan dijamin sah.

Dibaca dari aspek pertahanan kekinian, penggunaan sistem operasi jahitan asli anak-anak negeri ini, akan mendorong tumbuhnya prinsip kedaulatan digital di jagat maya Indonesia sekaligus antisipasi dini terhadap potensi ancaman peperangan komputasi (cyberwar). Komunitas Santri Informatika Ponpes SPMAA juga mengkampanyekan penggunaan internet secara sehat, aman, produktif dan positif bertanggungjawab. Melalui program Internet Keluarga (IGA) santri ponpes SPMAA berkeliling pesantren, lembaga pendidikan dan komunitas masyarakat di Pulau Jawa mengajarkan praktek berinternet sehat. Sasaran utama dari program ini adalah kaum ibu, wanita dan anak-anak remaja. Sebab merekalah yang rawan dan rentan dijadikan korban dampak negatif internet. Selain mendakwahkan sisi positif internet dan tindak antisipatif dampak negatif internet, Komunitas Santri Informatika juga mengkampanyekan kemandirian lewat jaringan gerakan Klik Indonesia. Misi dari kampanye ini adalah menggerakkan semangat kebangsaan dan ke-Indonesiaan di dunia maya dengan cara berdikari menggunakan sumber daya piranti teknologi informasi buatan anak Indonesia yang pada gilirannya memberikan keuntungan bagi generasi bangsa sendiri. Contohnya pemakaian domain .id sebagai identitas nasional warga atau komunitas Indonesia di dunia maya. Juga pemanfaatan jasa pengembang piranti 
lunak (developer) lokal, penyewaan server lokal, serta pemakaian piranti lunak lokal seperti Zohib (messenger chat), Sebangsa atau Kita (media jejaring sosial) dan BlankOn (sistem operasi komputer).

Peran santri Komunitas Santri Informatika di sini adalah giat pertahanan membela negara dalam bingkai kehormatan keluarga beserta harga jati diri bangsa (hifzhun nasl) sekaligus membangun sinergitas kekuatan strategis untuk menghadapi ancaman peperangan asimetris lewat piranti teknologi informasi.

\subsubsection{Pendidikan Informasi Lingkungan Hidup (PILIH)}

Unit program pembelajaran ini diproyeksikan sebagai lahan amal pembuktian santri pecinta lingkungan (amaliyah alamiyah) sekaligus wujud pelaksanaan Islam menghadirkan rahmat bagi seluruh alam. Diantara produk layanan PILIH yang kini diikuti para santri adalah (1) KELOMPOK SANTRI PECINTA ALAM \& LINGKUNGAN (KSATRIAKU), tempat santri berorganisasi menyalurkan hobi pecinta alam beserta lingkup giat pelestarian lingkungan di dalamnya; (2) PELESTARIAN TANAMAN LANGKA (PATAKA) kegiatan santri mendaftar, menanam, dan membudidayakan aneka jenis tanaman (buah, bunga, pepohonan, sayuran, dII) asli Indonesia yang mulai langka keberadaannya; (3) WALI LINGKUNGAN adalah pribadi setiap santri yang wajib memiliki kepedulian menjaga kebersihan dan kerapian lingkungan, contohnya menata, menjaga, dan merawat sandal di setiap sudut komplek (Wali Sandal), komunitas penyayang binatang, dll; (4) DAI DIVER ialah kegiatan komunitas santri yang hobi menyelam untuk misi studi syukur bahari dan kampanye penyadaran, perlindungan serta penjagaan potensi kemaritiman -meliputi sumber daya alam dan manusia-negara Indonesia; (5) ECO PESANTREN ialah unit percontohan program Pesantren berwawasan lingkungan. Di sini kurikulum pendidikan pesantren dan semua pegiat beserta sarana prasarana yang tersedia di dalamnya didesain memiliki aspek lingkungan yang berkelanjutan. Untuk saat ini Yayasan Ponpes SPMAA merupakan pondok pesantren percontohan ECO
PESANTREN di wilayah Jawa Timur; (6) ENVIRONTMENT PARLIAMENT WATCH (EPW) ialah giat praktek santri dalam upaya advokasi kebijakan pro-lingkungan kepada para anggota dewan di parlemen.

Peran dukungan santri di unit-unit kegiatan praktek belajar ini adalah upaya menjaga, melindungi dan melestarikan aset-aset berharga milik bangsa Indonesia di bidang lingkungan (hifzhul maal) agar terus memberikan manfaat buat sebesarsebesarnya kesejahteraan masyarakat dan tidak hilang percuma akibat dicuri pihakpihak yang tidak berhak.

\subsubsection{Tenaga Penyayang Umat (Caregiver Cadre)}

Setiap santri Ponpes SPMAA pada akhirnya akan dibentuk menjadi seorang Tenaga Penyayang Umat (TPU) melalui jenjang pendidikan kader para santri peduli (caregiver cadre). Secara teknis dalam pelaksanaan kurikulum pembelajaran pesantren, para santri dikondisikan wajib dan harus pernah merawat dan atau mengasuh santri lain yang berkebutuhan khusus (misalnya santri difabel lanjut usia atau santri stateless bayi balita) dalam jangka waktu terjadwal. Pembelajaran ini menanamkan dan menumbuhkan kesadaran para santri tentang pentingnya membumikan ajaran agama ke dalam praktek-praktek terbaik yang langsung bermanfaat bagi umat. Santri selain diajarkan teori literasi kitab suci, sekaligus harus bisa melaksanakannya segera. Satu ayat didapat, satu perbuatan manfaat bisa diamalkan saat itu juga. Sehingga para santri tidak hanya puas didaulat menjadi seorang "ustadz", tetapi lebih dari itu mereka punya amanat sebagai penggembala dan penyayang umat. Prakteknya, santri TPU caregive rcadre ini akan beraktifitas penuh waktu mengasuh santri lainnya yang berkebutuhan khusus. Aktifitas mulai dari memandikan, menyuapi makan, mengganti popok, membersihkan kotoran, menyiapkan pakaian, mengantarkan ke masjid, berbagi cerita (telling story) sebagai bagian pemulihan psikososial, dan aktivitas lain pengasuhan keperawatan. Para santri akan seterusnya menyandang profesi TPU. Sebab di dalam tradisi keilmuan santri Ponpes SPMAA ini, tidak ada kata "alumni" sebagai tanda usai 
mengabdi. Menjadi santri adalah profesi abadi. Belajar sepanjang hayat dikandung jadad sebagaimana tradisi pembelajaran Nabi. Sehingga diharapkan ketika para santri kembali ke keluarga di daerahnya atau menjalankan misi penugasan pelayanan, kesukarelawanan amal dan kesetiakawanan sosial ini akan terus bergiat semangat hingga istirahat wafat.

Dalam konteks pertahanan negara nirmiliter, apa yang dipraktekkan santri Ponpes SPMAA ini merupakan pendidikan, pengamalan, serta penjagaan hakikat dari ideologi PANCASILA secara konsisten, utuh dan konsekwen. Upaya para santri filantropi ini sekaligus belajar berikhtiar membentengi diri (hifzhul 'aqh) dalam bingkai bela agama, bela bangsa dan bela negara (hifzhud diin) dari ancaman aktual serangan idelogi lain yang ingin mengubah dasar negara serta budaya baik Indonesia. Misalnya melalui media penyebaran paham pola hedonis, egois konsumtif, gaya hidup junkies, dan sub-budaya isme laten lainnya yang menyasar keluarga remaja Indonesia.

\subsubsection{Belajar Bersama Masyarakat (BBM) \\ Kegiatan pembelajaran Belajar}

Bersama Masyarakat (BBM) santri ini dibagi menjadi sesi asrama dan sesi luar asrama. Sesi asrama mengkondisikan santri belajar bersama pembelajar lainnya dari luar lingkungan pesantren misalnya, mentoring santri-mahasiswa, live in santrisuster biarawati, dan pelatihan dukungan pengembangan pengetahuan bagi kecakapan hidup santri. Sesi luar asrama mengharuskan para santri bergiat misi ke daerah atau wilayah yang ditentukan pengasuh pesantren. Batasan usia belajar santri menentukan jangkauan wilayah yang akan dirambah. Untuk usia sekolah menengah pertama (SMP/Tsanawiyah), santri peserta BBM akan disebar ke daerah kecamatan di sekitar kabupaten secara berpasangan dan atau tim berkelompok. Untuk usia sekolah menengah umum (SMU), santri peserta BBM diberangkatkan misi ke daerah kabupaten/kota di propinsi Jawa Timur secara mandiri, satu santri satu kabupaten. Sedangkan untuk usia paska sekolah formal (SMU/Aliyah), peserta santri BBM ini akan dikirim ke pulau-pulau terluar di perbatasan wilayah
Indonesia. Batas waktu misi penugasan BBM ini adalah 2 (dua) minggu untuk usia SMP/MTs, 1 (satu) bulan untuk usia SMU/MA, dan minimal 7 (tujuh) bulan hingga seterusnya untuk usia paska sekolah madrasah aliyah.

Pada hakikatnya peserta santri BBM ini akan belajar mendadar jatidiri santri Indonesia sebagai kader bela negara yang berkemampuan memadai dan selalu siap pakai. Secara bertahap, bertingkat, dan berlanjut santri peserta BBM akan berlatih mental survival, analisa pemetaan sosial, fungsi sadar teritorial, potensi kekayaan sumber daya alam di lingkungan perbatasan, dan terutama belajar memahami serta menerima khazanah budaya Indonesia yang berwawasan nusantara dan berpola Bhinneka Tunggal Ika. Dalam misi pelayanannya, santri peserta BBM ini dibekali surat tugas resmi dan berkoordinasi dengan aparat setempat yang berwenang meliputi TNI/Polri serta dinas pemerintahan terkait. Khusus BBM di pulau terluar, pesantren menyediakan peserta tiket dan bekal cukup sekali jalan. Selama 7 bulan misi layanan, mereka akan praktek pengasuhan, pembelajaran dan pengabdian seperti jadi guru bantu, marbot masjid, pendamping keluarga telantar dan aktivitas pekerja sosial lainnya secara mandiri sukarela.

\subsubsection{Kepanduan}

Unit kegiatan pembelajaran santri ini merupakan praktek keterampilan kepanduan dengan tujuan memperkuat semangat kebangsaan dan kelndonesiaan melalui ekstra kurikuler sekolah. Dalam giatnya, kepanduan SPMAA mengikuti struktur organisasi dan arahan pembinaan kepanduan Pramuka Indonesia. Setiap personel santri Ponpes SPMAA adalah berkepanduan Pramuka yang berjiwa Pancasila, berpamrih Merah Putih, berbakti mengabdi NKRI serta berwawasan nusantara. Kepanduan ponpes SPMAA saat ini berada di bawah pembinaan Satuan Karya Wira Kartika (SAKA WIRA KARTIKA) TNI-AD dengan tetap disiplin berorgan kepramukaan ke koordinasi Kwartir Ranting (Kwaran) hingga Kwartir Nasional (Kwarnas).

\subsubsection{Dai Kamtibmas}


Unit program ini merupakan wadah inisiasi kerjasama Ponpes SPMAA dan Kepolisian Negara Republik Indonesia (Polri), khususnya Polda Jatim, dalam giat kampanye cipta kondisi keamanan dan ketertiban masyarakat (Kamtibnas) serta upaya sadar penegakan hukum terpadu (Gakkumdu). Dalam prakteknya setiap pribadi santri Ponpes SPMAA harus memiliki etika seorang pendakwah yang berketeladanan kebaikan meliputi ucapan, pikiran, dan tindakan. Sebagai seorang santri yang diproyeksi menjadi sumber rujukan jawaban dari dinamika persoalan umat kekinian, figur Dai Kamtibmas dituntut mampu mempraktekkan norma dan doktrin bela negara dalam setiap aktivitas dakwahnya. Sehingga dengan program pembelajaran Dai Kamtibmas ini, para santri berperan sekaligus sebagai komponen pendukung pertahanan negara lewat giat penjagaan ketertiban dan keamanan.

\section{PENUTUP}

Kesimpulan dan saran yang dapat di tarik adalah:

1. Pondok pesantren dan santri di Indonesia yang berjumlah melimpah ini dapat diproyeksi sebagai komponen cadangan serta komponen pendukung upaya pertahanan negara (hanneg) dari aspek nirmiliter. Potensi kekuatan sumber daya manusia (human wave) dapat dipadukan dengan latihanlatihan pendidikan mental, keterampilan survival dan kepedulian sosial yang nanti berfungsi membentuk sinergi pertahanan integratif (total defense).

2. Pesantren dan komunitas santri telah lama mempraktekkan giat bela negara dalam proses pembelajarannya, baik lingkup skala kecil menjaga diri dan lingkungannya di asrama maupun skala luas saat penugasan menjaga serta melindungi aset budaya dan potensi kekayaan sumber daya alam negara. Sejarah telah mencatat rekaman pengabdian laskar-laskar jihad perlawanan rakyat dari unsur santri saat revolusi fisik perjuangan merebut kemerdekaan maupun mempertahankan proklamasi kemerdekaan. Keniscayaan ini harus diakui dan kemudian diarahkan menuju semangat bela negara dalam kondisi kekinian, terutama menghadapi ancaman perang asimetris dan ideologis.

3. Pendidikan Pendahuluan Bela Negara hendaknya didorong dan diformulasikan lebih kepada praktekpraktek nyata giat aktivitas yang langsung bermanfaat buat masyarakat sesuai bidang minat di mana santri atau komunitas bertempat. Pemerintah diharapkan memfasilitasi Pendidikan Pendahuluan Bela Negara ini terutama ke lembaga pengelola pendidikan dengan pendekatan wawasan kebangsaan serta nilai kearifan lokal yang dianut masyarakat. Perlu dievaluasi kembali paradigma lama yang berangkat dari stigma media bahwa agama tertentu atau komunitas tertentu santri dan pesantren misalnya membawa kecenderungan ajaran kekerasan.

4. Santri memahami hakikat bela agama, bela bangsa dan bela negara adalah berangkat dari niat serta semangat menjaga hak-hak dasar setiap manusia (adz-dzoruriah alkhamsah). Untuk memperjuangkan hak dasar ini, militansi santri akan terejawantah dalam layanan misi sosial kemasyarakatan dengan keyakinan Berdoa Ikhlas, Bekerja Keras, dan Belajar Cerdas.

5. Praktek-praktek terbaik santri Yayasan Ponpes Sumber Pendidikan Mental Agama Allah (SPMAA) membuktikan bahwa semangat jihad dengan motto INGAT ALLAH, INGAT MATI, dan KASIH SESAMA bisa diarahkan kepada aktivitas positif membangun dan menanamkan kesadaran bela negara di bidang layanan pendidikan, kesejahteraan sosial dan pelestarian sumber daya alam lingkungan / keanekaragaman hayati. Secara teknis praktek bela negara itu dirumuskan dalam unit kegiatan kepesantrenan di lingkungan asrama maupun di luar asrama yang dapat memberikan manfaat buat masyarakat. Unit kegiatan ini diformulasikan ke dalam kurikulum pembelajaran integral yang bisa 
direplikasi dan diduplikasi oleh lembaga pengelola pendidikan lainnya sebagai komponen pendukung upaya pertahanan negara.

6. Konsep ideal pertahanan negara integratif dari aspek nirmiliter dapat diikhtiari melalui pendekatan kesejahteraan (social prosperity approach) dan itu mencakup usaha bersama segenap komponen bangsa. Kesejahteraan umum meliputi upaya pencerdasan bangsa adalah amanat Pembukaan Undang-Undang Dasar 1945 yang harus dilaksanakan sebagai kewajiban bela negara dan hak bela bangsa dan pada gilirannya akan mendukung penguatan strategi pertahanan.

7. Pelaksanaan giat bela negara harus mengedepankan kesukarerelawanan, pengorbanan, keikhlasan, masa depan kemanusiaan dan tanggung jawabkeakhiratan sebagai prinsip dasar. Hal ini sudah diawali para pendahulu kita seperti Pangeran Diponegoro dan Panglima Besar Jenderal Sudirman yang rela berkorban serta ikhlas berjuang meninggalkan kenyamanan demi melawan kezaliman penjajahan. Semangat prinsip dasar ini yang harus ditumbuhkembangkan kembali pada nalar generasi kita sekaligus sebagai upaya perlawanan terhadap ancaman perang asimetris melalui penetrasi ideologi hedonis, egois, junkies, dan isme-isme pragmatis yang menggerogoti jiwa korsa, membunuh ruh PANCASILA, dan menghancurkan ikatan persaudaraan kelndonesiaan.

\section{DAFTAR PUSTAKA}

ErisHerryanto, 2012. Sambutan Sekretaris Jenderal Kementerian Pertahanan Republik Indonesia, Konsep Pertahanan Negara Kepulauan dalam Menghadapi Perang Asimetris", pada acara Seminar Nasional Pertahanan di Akademi Angkatan Udara 2012.
Kemenag.go.id, Analisis dan Interpretasi Data pada Pondok Pesantren, Madrasah Diniyah (Madin), Taman Pendidikan Qur'an (TPQ) Tahun Pelajaran 2011-2012, dalam http://pendis.kemenag.go.id/file/doku men/pontrenanalisis.pdf, diakses pada tanggal 19 Desember 2014.

Zamakhsyari Dhofier, 1982. Tradisi Pesantren: Studi Tentang Pandangan Hidup Kyai. Jakarta: LP3ES. 